\title{
Conveyance of preaching by vulnerable listeners - A case study of farm workers in the Vredefort Dome South Africa
}

\begin{abstract}
Author:
Barend J. de Klerk ${ }^{1}$

Affiliation:

${ }^{1}$ Practical Theology, Faculty of Theology, North-West

University, South Africa

\section{Correspondence to:}

Barend de Klerk

Email:

ben.deklerk@nwu.ac.za

Postal address:

PO Box 20764, Noordbrug

2522, South Africa

Dates:

Received: 10 July 2014

Accepted: 14 Oct. 2014

Published: 04 Mar. 2015

How to cite this article: De Klerk, B.J., 2015, 'Conveyance of preaching by vulnerable listeners - A case study of farm workers in the Vredefort Dome South Africa', In die Skriflig 49(1), Art. \#1859, 8 pages. http:// dx.doi.org/10.4102/ids. v49i1.1859
\end{abstract}

\section{Copyright:}

(c) 2015. The Authors. Licensee: AOSIS

OpenJournals. This work is licensed under the Creative Commons Attribution License.

Read online:
Farm workers living in and around the Vredefort Dome World Heritage Site are some of the most vulnerable people in South Africa. Research by means of a case study with four participants from this group examined the following question: How do vulnerable people continue preaching the Word in this environment by ministering to other vulnerable people with the sermons that they have heard? The case study considered both the environment and the circumstances in which these participants live. This research aimed to establish what it means to preach to those who are vulnerable and how such preaching can be continued by the hearers. A case study by means of a qualitative empirical investigation called upon a few of the vulnerable hearers to speak. The findings included that the participants to this case study do not spread the sermons further on a regular basis, but they would be able to edify and encourage other vulnerable persons with it if needed. If they do talk to each other about the sermon directly after the worship service (like it was done during the interviews), their confidence to proclaim the message to other vulnerable people who do not participate in the worship services will increase.

Die voortdra van prediking deur weerlose luisteraars - 'n Gevallestudie rakende plaaswerkers in die Vredefortkoepel in Suid-Afrika. laaswerkers wat in die omgewing van die wêrelderfenisgebied, die Vredefortkoepel, woon, is van die mees weerlose wesens in SuidAfrika. 'n Gevallestudie, waaraan vier van hierdie persone deelgeneem het, is gedoen. Dit het oor die volgende vraag gehandel: Hoe word preke wat aan weerloses bedien word deur hulle aan ander in hulle omgewing wat in dieselfde omstandighede verkeer, voortgedra? Die omgewing waarin die deelnemers woon en hulle lewensomstandighede is nagegaan. Daar is gepoog om vas te stel wat onder prediking aan weerloses verstaan word en hoe sodanige prediking deur die hoorders verder versprei kan word. Die gevallestudie, wat deur middel van 'n kwalitatiewe empiriese ondersoek plaasgevind het, het enkele van die weerlose hoorders self aan die woord laat kom. Die bevinding was dat die deelnemers hieraan nie die preke op 'n gereelde basis verder laat weerklink nie, maar dat hulle wel in staat sou wees om ander weerlose persone daarmee te versterk en te bemoedig. Indien hulle wel onmiddellik na die diens met mekaar oor die preek van die dag sou gesels (soos dit in die onderhoude gedoen is), kan die vrymoedigheid groei om die boodskap ook aan ander weerlose mense wat nie aan die erediens deelgeneem het nie, oor te dra.

\section{Introduction}

Every country in the world, including South Africa, has vulnerable people. The long history of Apartheid left the country with many vulnerable people who remained so after the transition to a democratic South Africa (Benatar 2001:350). This state of affairs has changed a little after 20 years of democracy. Some of those who were vulnerable during the apartheid era are now in positions of power and a new group of vulnerable persons has been added to the numerous masses. Pieterse (2009) describes vulnerability as follows:

Vulnerability originates when an individual can not bring about the desired outcome by means of his or her own behaviour. Such a person is unable to influence events through his or her own behaviour. (pp. 259-260)

The emphasis of this investigation is not on the preacher or on the vulnerable listeners, but it focuses on if and how such listeners spread the content of the sermon(s) they heard and internalised it to other vulnerable persons in their environment. Research on the conveyance of preaching is scarce, but is necessary in the field of homiletics. The environment where the research took place is the Vredefort Dome World Heritage Site (VDWHS). This area was proclaimed a world 
heritage site in 2005 and has since been transformed into a tourist paradise as a result (Gibson \& Reimold 2008:34). The beautiful environment, wealthy land owners and managers of tourist facilities are in stark contrast to the average farm workers and their families. These labourers live in the region and have been doing so long before the Vredefort Dome was declared a world heritage site. In all this time nothing much has changed for them.

The group of farm workers who constitute the Venterskroon congregation has an interesting church history. Students from the North-West University Potchefstroom Campus (about $30 \mathrm{~km}$ from the VDWHS) started 15 years ago to minister to the children of the area every Sunday with spiritual conversation, song, enactment of biblical events and relaxation. After a few years the parents also requested ministry. The church ministry they were exposed to up until that point was sporadic visits from a spiritual leader once a month who demanded financial contributions from the believers. They were threatened with deprival of a funeral should they not contribute. Suddenly they found that a different church group was willing to minister to them every Sunday without asking any money. The group soon got a permanent minister and in addition to visible growth in faith, the group also grew in numbers.

The question investigated in this article is: How do vulnerable people continue the act of preaching in their area by ministering to other vulnerable persons with the sermons they heard? The following aspects will be discussed briefly: What does the environment entail? What are the circumstances in which the farm workers find themselves in general? What is meant by preaching vulnerability that is carried further by the headers? A few of these vulnerable hearers will be heard by means of a qualitative empirical investigation in the form of a case study and a few findings will be noted.

\section{The Vredefort Dome World Heritage Site}

The regional context for the research is the VDWHS, South Africa, considered the world's oldest (2.023 million years) and largest $(190 \mathrm{~km})$ visible meteorite impact site. The Vredefort Dome, approximately $120 \mathrm{~km}$ south west of Johannesburg, is a representative part of a larger meteorite impact structure or astrobleme and has been declared South Africa's 7th World Heritage Site in 2005 . With a radius of $190 \mathrm{~km}$, it is also the largest and the most severely eroded (Gibson \& Reimold 2008:12). The Vredefort Dome bears witness to the world's greatest known single energy release event, which caused devastating global change, including, according to some scientists, major evolutionary changes (Gibson \& Reimold 2008:34). It provides critical evidence of the earth's geological history and is crucial to our understanding of the evolution of the planet. Despite its importance for the planet's history, geological activity on the earth's surface has led to the disappearance of the evidence from most impact sites and Vredefort is the only example on earth that can provide a full geological profile of an astrobleme below the crater floor (cf. Puren, Drewes \& Roos 2008:134-136; Jordaan, Puren \& Roos 2008:92-94).
The original crater, now eroded, is estimated to have been $250-300 \mathrm{~km}$ in diameter. The ring of hills at Vredefort is composed of granitic gneiss rock. To make a crater $300 \mathrm{~km}$ wide, the meteorite must have been about $10 \mathrm{~km}$ across (as big as a mountain) and travelling at more than $10 \mathrm{~km}$ per second or $36000 \mathrm{~km}$ per hour (Gibson \& Reimold 2008:53). The Vredefort Dome is only the centre part of the impact crater. It is called a dome, because the rock layers were bent into the shape of an upside-down bowl $90 \mathrm{~km}$ across by the impact. The explosion was million times more powerful than the biggest atomic bomb ever built on earth. If it happened today it would kill almost all living things and beings on earth (Gibson \& Reimold 2008:60).

The ongoing debate regarding the endogenic versus exogenic origin of many circular structures on earth hinges on observations, data, methodologies and modelling that have their roots in classic studies of the Vredefort Dome (cf. Gibson \& Reimold 2008:116). It is mainly for these reasons that in July 2005, the north-western part of the dome was declared a World Heritage Site.

\section{Puren et al. (2008) described the environment:}

It is a unique natural landscape filled with rolling hills, rocky outcrops and a unique composition of indigenous fauna and flora. At least 100 plant species, over 50 mammal species and 70 different butterfly species have been recorded in the area. Abundant vegetation includes 99 identified plant species and the largest wild olive forest in South Africa. These, together with the more than 450 identified bird species, 70 butterfly species, and rare fauna such as the rooikat, aardwolf, leopard, and rock dassie, are important tourist attractions and a major influx of tourists into the area is anticipated in the near feature. (cf. pp. 140-142)

\section{The work and living conditions of the farm workers}

The work and living conditions of the farm workers in the Vredefort Dome region do not differ much from the circumstances of farm workers in South Africa in general.

Despite of the democratisation of South Africa in 1994, which brought the agricultural sector within the ambit of legal protection, farm workers remain vulnerable to an undue burden of social and health problems (London 2003:59). Labour conditions on South African farms are amongst the worst of all employment sectors. Until recently, farm work was effectively unregulated and dominated by a culture of paternalism, which was not always free of violent coercion (London 2003:60). Historically, very little labour protection was given to farm workers. However, labour relations are currently governed by specific labour legislation concerning working hours and minimum wages (Orkin \& Njobe 2000:43). Given the low skills content of farm work as practiced in South African agriculture, farm work, in many senses, represents the opposite of a healthy-worker cohort - a repository for a low-skill, high-morbidity, eminently controllable working population (London 2003:65). 
Woolman and Bishop (2007:576) indicate that farm workers may perhaps not be treated like slaves, but that their status is nothing more than so-called servitudes. They (Woolman \& Bishop 2007) provide the following definition of servitude:

Servitude is about caste or status. Persons in conditions of servitude occupy a social station that does not allow them to alter the conditions of their existence: their station makes it appear that they work 'voluntarily' for those above them. (p. 597)

The marginalised status of the farm workers is also reflected in their living conditions.

Farm workers usually live in houses that do not belong to them. A central component of the arrangements on farms is that many workers not only work on the farms, but also live there, with housing being either a form of payment in kind, or part of the terms of their contract. Thus, for many farm workers, the loss of their job means the loss of their house. The farmer is able to exercise control over the farm workers' daily bread and the roof over their heads. This increases farm workers' dependence on the farmer and contributes significantly to the imbalance of power (Woolman \& Bishop 2007:598).

Farm workers and their dependants have historically existed in closed communities, dependent on farmers, with low levels of education, gaining in situ training, but with little experience of or access to alternative employment (Hartwig \& Marais 2005:934). This places constraints on economic relevance in light of a changing economy as well as changing farming practices, including the trend towards mechanisation. Historically, low wages have been a reality on farms, even taking into account crop share, other rations and the provision of free housing and services (Atkinson et al. 2003:13). Related to the issue of dependency, Atkinson et al. (2002:42; 2003:15) note the difficulties and frustration of farm workers who experience a lack of transportation. Low levels of service delivery and poor public transportation result in dependence on the farmers for mobility, whilst isolating farm workers from alternative support mechanisms. The need for affordable rural transportation for farm workers is of paramount importance in order to ensure farm workers' socio-economic inclusion. Limitations in access to healthcare are primarily due to physical constraints in mobility (Atkinson et al. 2003:20). This is particularly true with regard to the needs of rural women, elderly people and children who do not have access to appropriate schooling, healthcare and other social amenities, increasingly only available in urban areas (Hartwig \& Marais 2005:934).

Education levels of farm workers are low, particularly the older generation with estimates of illiteracy in the order of $20 \%-30 \%$ and average schooling levels of five years. Access to health services for farm workers is severely constrained by their dependence on their employers for transport and rural health and social services are grossly under resourced in rural farming areas. A rough estimate on the basis of the 2001 census reveals that more than $50 \%$ of farm workers do not have access to adequate sanitation and access to water is also substandard (Statistics South Africa 2004).
Another point of interest about the farm labourers in the Vredefort Dome is that there is a greater discrepancy between the living conditions of the farm owners and the farm workers. The economic indicators of the area reflect a marked difference between people in the high socio-economic bracket and those in the low socio-economic bracket (mostly farm workers). Land owners, who constitute $34.98 \%$ of the residents, can provide adequately for themselves in terms of leisure activities, food and transport, whilst workers (42.38\%) lack basic services and economic opportunities to provide for their most basic own needs (Puren et al. 2008:137).

Some of the farm workers' families had to move to the informal settlement just outside town in order to survive and/or for the education of their children. The loss of a sense of place created havoc with the traditional lifestyle, effectively destroying the core values and traditions of a whole rural community. The influence of loss of place on identity can be remarkable because of the role places have in forming and affirming a sense of personal identity (Jordaan et al. 2008:105). Farm workers in the Vredefort Dome can be regarded as vulnerable people.

\section{Inspiration for vulnerable people to convey the sermon further}

What can inspire these vulnerable people to carry the sermon further? In 1 Thessalonians 1:8 Paul relates how the Word of the Lord spread from the believers in Thessalonica to Macedonia and Agaje. The participants to the worship service can echo the Word so that it reaches others, even to such a degree that the preacher has to say no more. Vulnerable listeners can even become preachers themselves as they become more and more convinced of God's vulnerability, of their own status as new people in Christ despite their own vulnerability and as they see the vulnerability of the preacher and understand the unique nature of the message.

God suffers with his children. Jeremiah preaches to his people about how God experiences their anxieties and fears. God speaks in Jeremiah's voice: 'You who are my Comforter, my heart is faint within me ... Since my people are crushed, I am crushed' (Jr 8:18, 21). God feels their pain. 'It seems clear that we can infer from this passage that God also feels our pain, is suffering because we have been hurt' (HinsonHasty 2002:130). God is always working in his children alsoespecially during times of vulnerability. He does this as the suffering God who languishes, mourns and feels pain with us and who reacts to this. 'God enters fully into the hurtful situation and makes it his own. Yet, whilst God suffers with the people, God is not powerless to do anything about it' (Fretheim 1984:128). His actions are focused on redemption from the cause of pain and sadness.

God's vulnerability becomes visible in a special way when Jesus relinquishes all earthly power and becomes the victim of the condemnation and hate of those in his environment. His vulnerability reaches its pinnacle on the cross where he is not able to save himself, when God is silent and pours out 
his wrath over Christ who is God-forsaken, and rebellious people seemingly triumph over him (Berkhof 1979:135). The resurrection confirms that the cross does not signify the power of men over God, but rather a victory. The Holy Spirit also goes through the gates of vulnerability by being resisted and saddened. When he radically changes people's hearts, these people are often made vulnerable and have to turn the other cheek rather than to take revenge (Jensen 2005:31). Yet the Holy Spirit is still making people children of God through the power of forgiveness and renewal.

The vulnerable can be further inspired to continue preaching by viewing their vulnerability in light of the new status they have in Christ. Marginalised people who cannot reach the outcome that they want to reach through their own actions can be described as follows (Campbell 2002):

Their human interest in living is narrowed to meagre subsisting; their hope for life is no more than avoiding involvement with other humans and a desire that no one will bother them (p. 36)

The best example is the poor in our society. The poor are those people who can not become participants to broader society due to oppressing circumstances. They remain marginal figures (Pieterse 2013:3). However, poverty and human suffering cannot take away people's human dignity, because God believers in Christ are new people and unbelievers (although skewed) are still image bearers of God. Preaching should help people realise the integrity of their identity and should help them keep this integrity.

The fact that preachers themselves are vulnerable and become even more vulnerable as a result of their ministry can contribute to the vulnerable listener's confidence to carry this ministry further. De Klerk, De Wet and Letsosa (2010) explain:

The preacher should communicate the all-disclosing Word of God not only to reveal the truth about the vulnerability of the listeners and the world in which they live in, but also about his own vulnerability: He is vulnerable in not always having ready prepared clever answers. He is vulnerable in that he is totally dependent on the grace of God and is in himself totally exposed to the onslaught of the enemies of God and his children. He cannot speak one word without communicating with his whole being that it is through grace alone that he can minister the Word of God. (p. 106)

Preachers are called to speak on behalf of those who are vulnerable in our churches, societies and the world (Ottoni-Wilhelm 2014:1). The vulnerable preacher should communicate with listeners (fellow vulnerable human beings) deeply and authentically. Together they should find a fullness of life in a living relationship with God and in being crucified with Christ (Ottoni-Wilhelm 2014:1). OttoniWilhelm (2014) also says that:

Preaching is risky when preachers realize that their studying, praying, exploring, and speaking is never exhaustive or complete - they are always at risk of misunderstanding something about God, themselves, their people, and their contexts. They are also vulnerable when they choose to reveal something of their struggles, limitations, and uncertainties while addressing a particular sermon theme or context. (p. 1)
The power of preaching and continued preaching will inspire the continuation of the preaching by the listeners. Long (2001:18) explains that the worship service is about people who are changed by the presence of God and his Word. The aim of preaching is not merely that those on the other end should listen, but that there should be a change in attitude and that the listeners should be empowered to be preachers themselves and to carry the sermon further. Preaching aims to provide information (to address the intellect), touch the hearers emotionally (address the emotions), but, ultimately, the goal is to move them to action (address the will) and to inspire them to witness (let them speak). Preaching should bring hope, both through the preacher and the one that carries the sermon further. Mathews (2013) says that:

Jesus' preaching brought a message of hope and reconciliation to his vulnerable hearers. The core of his message ('the righteousness of the Kingdom') focused on healing relationships through loving service. (p. 125)

Hermelink (2007:41) states that hope is on the one hand something that should be received - it should be revealed to people; people should listen to the voice of hope during preaching and should take this for themselves. On the other hand hope is also a deed of the listeners. The hearers are expected to proclaim Christ through words and behaviours. Hope changes the way in which you live your life. Preaching can therefore be understood as empowerment to hope. The aim of preaching hope is to shape hearers so that they will, in turn, speak that hope. It should bring hearers to the point where they can express their own hope with their own voices. Preaching hope empowers the hearers to become responsible, self-providing witnesses of what they have seen, heard and read. It means empowering people so that they cannot but become preachers of hope (Hermelink 2007:42-43).

The congregation's involvement in preaching reaches beyond the activities of preparation, planning and listening. The congregation should teach each other from the Scripture reading and preaching (cf. Heb 5:12, Desilva 2000:71), and they should help each other to carry the Scripture reading and preaching further into practice. The aim is to stimulate the responsibility and participation of ordinary believers about Scripture reading and preaching. The content of 1 Corinthians 14 about the gift of prophecy is decisive for the practical application thereof in the life of the congregation at that specific time (De Klerk 2013:290). The way in which the congregation carries the preaching further or fails to do so could weaken and de-reform preaching. The reformed congregation is revealed to be underage, an ecclesia audiens, a church that only listens and remains silent forever. To counteract this devaluation of the preaching events, we now refer to the so-called 16th century prophecy (De Klerk 2013:290).

The experience of Calvin at that time, and later of Voetius and Labadie, was that prophecy had a bigger influence than the most powerful sermons, and that it promoted the growth of the congregation strongly (Desilva 2000:83-85). Prophecy, in the context of 1 Corinthians 14, is not to forecast future things, but to interpret Scripture concretely and to 
apply the interpretation in consoling and admonishing the congregation (Hall 2003:144). In the context of 1 Corinthians 14 , a prophet is someone who, under the illumination of the Holy Spirit, has the gift to perceive and proclaim the hand and will of God in the existence and history of the people of God. Prophecy is above all the gift to understand and express what the will of God would be in a concrete, given situation (Ac 11:28; 13:1; 15:32). In practice, it means that the insight of people into the Word of God is used to console and encourage the congregation by revealing God's governance (Green 2002:265). As prophecy is applied to build up the congregation, special room must be made for the prophetic word in the congregation (1 Cor 14:39; cf. Rm 12:6, 7; 1 Th 5:20; De Klerk 2013:292).

The ministry of the Word is dedicated to the whole congregation and every member has the responsibility to contribute, because all of them should eagerly desire for the gift of prophesy (1 Cor 14:1). It is important to explain constantly to the members of the congregation that there is little value in it to only listen to the Word of God and not doing what the Word asks from them. A confessing response must follow upon the Word service (De Klerk 2013:293). Practically, it means that every member should develop the gift to apply God's Word in different situations of life. The agreement should be the following: we are using the gift of applying the Word of God concretely, and therefore members are now going to work together to draw lines from God's Word to situations in everyday life (Kim 2006:149).

It is based on the preceding argument that one can now consider the case study to establish the involvement of the farm workers in the Vredefort Dome region in the continuation of the preaching.

\section{Qualitative research}

A qualitative research design was used in this research, because it is an appropriate method to investigate research phenomena to obtain insight into the subjective experiences of people and to access the meanings they attach to the relational dimensions between them and the specific rural location. Furthermore, a qualitative research approach is particularly useful as an inductive, naturalistic approach to investigate unfamiliar research topics (Puren et al. 2011:1). A qualitative method is appropriate, because firstly, the research is conducted in a natural setting; secondly, it attempts to explore the sense of place in terms of the meanings people attach to a specific environment; and thirdly, there is no attempt to control extraneous influences, therefore comparing and contrasting perceptions. Rather, it attempts to put pieces of the reality together (Denzin \& Lincoln 2005:16).

Qualitative research has a personal quality as the researcher does not gather information from a distance, but through personal contact. It is a client centred approach in as much as the client's thoughts, actions and emotions are dominant.
It might be possible to make deductions from a qualitative research that might have some value as a generalised principle. Janse van Rensburg (2007) explains:

Qualitative research works on a much smaller scale than quantitative research. On average it may consist of four conversations with a particular individual or group. Participants are chosen in accordance with the research problem, hypotheses and goals of the research. (p. 4)

A qualitative interview is in essence actually a conversation during which the interviewer, because of his or her familiarity with the questions and topics under discussion, is able to steer the interview in a direction so that specific, predetermined topics are addressed (Babbie 2008:336).

In this research oral interviews with participants to the project were analysed to discover to what extent the participants convey the sermons further - one specific sermon in particular. Four persons were selected based on the fact that they are frequent participants to the sermons and form part of the group that may be regarded as vulnerable. Two women and two men participated in the study. Their ages ranged between 23 and 60 years. The following themes were selected, with the emphasis on the last two:

- Member's living conditions.

- Resounding preaching in general.

- Resounding the sermon of the day.

These themes were selected to first establish the degree of vulnerability and to then determine if and how these possible vulnerable members communicate to other vulnerable people about the sermons that they have heard. A few questions were formulated as part of each theme to make the conversation easier, but due to the unstructured nature of the interviews, these were not adhered to strictly. The interviews were not transcribed, but a summary (with the precise words) appears in this article. The full results of the interviews are in the safekeeping of the researcher.

\section{Member's living conditions}

The participants to the qualitative research all have reasonably good housing, although it is small, and in many cases too small for the number of people staying in the house. In comparison to the land owners and the new lodges that have sprung up in the area, the participants live in much smaller and simpler houses. However, one of the participants does experience housing problems, and she described it as follows: ${ }^{1}$ The living situation is not good because there are no sanitation and water. The participations experience their work circumstances as reasonably favourable, even though the remuneration is very small in comparison with what the land owners earn. The difference in quality is quite visible. One of the domestic workers relates her experience as follows:

I enjoy to work where I work.

1.The interviews were conducted in the mother tongue of the participants and were documented in English by the interviewer. 
The participants describe their lives as valuable, even though there is suffering that they have to handle. They for instance said:

My life is worthwhile because of God's love and because my family stuck together. I meet with other people who face the same challenges as I do and we can motivate each other. My life is worthwhile, because I can help my children and enable them to go to school. Through Jesus I can see progress in my life.

Their difficulties often centre on sustenance. One person described her embarrassment as follows:

Only one thing I do not like is to always ask from other people and not having my own things.

Another respondent spoke about the pain of being unemployed:

I am crying, because I am not working and failing to feed my family.

These difficult circumstances were described as follows:

Seeing people suffering from poverty, sickness (e.g. HIV / AIDS), struggling to get better education or to pay for their children's studies. There is serious poverty in the community.

Another said:

It is difficult not working to earn a salary and to provide for my children.

The interviews reveal that the church members are especially vulnerable when it comes to taking care of their families and the education of their children. In contradiction to this, the land owners are able to offer their children a tertiary education.

\section{Resounding preaching in general}

This section first gauges how preaching influences the lives of vulnerable people, especially since the emphasis is on the preaching that takes place every week. Some of the answers that reveal how the sermons influence the participants' lives in general sound as follows:

They make me think and look back at my life. They bring willingness to change a few things in future. I forgot how the world looks at me. I am able to see my mistakes. Sermons heal me spiritually. Sermons remind me of how I should conduct myself every day.

In discussion the focus was also on the question of whether these four people speak about the sermons. The general response was:

Not every day. Not about every sermon.

When they do speak to other vulnerable persons about the sermons, they discuss the following:

I share the things that touched me in that particular sermon. When the reverent have preached of something which is directed to my life, I use to sit down with my family and say: Did you hear what was said? I discuss the sermon even with those who did not come to church. I tell them about the examples made by the pastor.
During the discussion of how these participants use the sermons to comfort, encourage and edify other vulnerable persons, the following came to the fore:

I reread the scriptural passage that was read and I try to explain it to them. I help people to look at a specific text. I open Scripture and use the examples of the sermons. I refer to sermons which I once heard. I tell my sister to compare herself to Job who was sad but God comfort him. I spent some time sharing love and if their problem is too big, I refer them to the reverent.

One can deduce from the interviews that the participants do not witness about the sermons frequently. When they do so, it seems that they do use Scripture and that they attempt to explain the sermon with the Bible at hand. They quote the examples that were used during the sermon. These members are carriers of the sermons to their families and to people who are experiencing sadness, pain and insurmountable problems. The sermons are never discussed with employers or even co-workers, probably because these persons are more unapproachable and conversations with family members and other vulnerable people occur more spontaneously.

\section{Resounding the sermon of the day \\ Main points of the sermon ${ }^{2}$ preached at Venterskroon, Vredefort Dome, South Africa by Prof Rantoa Letšosa}

1 Peter 1:1-9: Strangers in the world but God's elected property: Most of us I believe have heard the word xenophobia. It means fearing strangers in the wrong manner and doing harm to them, because they appear to be a threat to you.

Peter is writing here to a group of Christians in the first place. They were deemed as strangers; even worse, they were exiles or refugees in these different places mentioned by Paul. They were called by names, they endured hardship, they had to rent flats or places for staying, and some were even slaves. It was very easy for the landlord to simply expel someone who rented at his place.

The world regards us as strangers. Peter says in this letter, irrespective of how the world looks at us, we have to remember that we are elected to serve God even in this tough situation. God elected them as his property. They are also people, who are sanctified by the Holy Spirit. They are now different people.

God's election is not without purpose. Election is unto obedience. We have to be obedient here on earth. All our suffering is the things of this world. Because of God's mercy, he has given a new birth into a living hope. We know that our misery now will turn into joy and time to come. We have an inheritance that is imperishable, undefiled, and unfading.

Right now, we go through hardships and trials. We are tested like gold by fire. Through our tests, we can see how weak and small we are and how great and merciful God is. Trials help to rely more and more on God. 
You might be staying in your mokhukhu [house made of sink] without your own ground. You might be employed and underpaid. You might suffer hunger and pain. Yet all these things cannot discredit you. We are God's elect and special, and this is not based on our earthly possession and what we have. Remember, mercy and grace! We have a calling and a challenge outside there - to be peace makers because we have been favoured by God.

\section{The four member's reaction on conveying the sermon of the day}

It is important to first determine what this sermon meant to the four participants personally and to hear what about this sermon they would want to convey to others. The following matters stood out from their remarks:

I understand that I am a foreigner in this world. The situation of xenophobia hurts my heart. God taught me how to treat foreigners with love and respect. I should not correct things by fighting but I should do it peacefully.

The reaction also included the view the believers have of themselves:

It taught me that the mercy of God is sufficient. I was touched by the part which said our faith in God is more precious than gold and silver, because it perishes. I learn the fact that I should not look down on myself that when things are not going accordingly with the political state of our country, I should not look down on myself. It made me realise that we, as Christians, should not hide away from challenges. It was very informative and practical, talking to some challenges I face in the area where I stay.

The above-mentioned comment makes it clear that the four participants listened to the sermon very carefully and that they could apply it to themselves. The sermon made an impression on them. What would they want to convey about this sermon to other vulnerable listeners? The discussion after the sermon focused on conveying the content of the sermon to vulnerable persons who are enduring inner pain and find themselves in difficult situations like poverty and disease. Only a few remarks not related to the relevant sermon were made, but that could be valid for any sermon. Three such remarks serve as an example:

Be strong and pray and everything will be fine. God has a plan with your life. They must believe in the living God, because he cares and love them.

How would the vulnerable listeners convey the content of the sermon of the day to vulnerable people who are enduring inner pain and find themselves in difficult situations like poverty and disease? This is perhaps the most important knowledge that we gained from the qualitative empirical interviews. For this reason one answer is quoted in full:

Our pain is temporary, because God chooses us. Whenever we are in poverty and sick it is only temporary. I will also learn them to share with those who are in poverty. Even if we are in trials and tribulations God promised us better life. If she is poor because of corruption, which is in our country, or if she cannot get help at the hospitals, she should solve things in a peaceful way. I should say do not stop trying even if it is hard, keep on trying in faith. I would tell them that they should keep their faith in Christ, because he is faithful. Our faith in God is more valuable than gold or silver. We are winning in whatever situation through Christ.

The remarks by the participants sketch a positive picture of what they would like to convey to other vulnerable persons from this sermon. However, one can not deduce from the answers if they actually do so. The experience of indicating after the worship service what they would like to convey and how they would do it may sensitise the participants to witness about the sermon in real situations.

\section{A few findings}

The participants to this case study are all vulnerable people who live and work with other vulnerable people. The first-mentioned group, as frequent participants in the worship services, has the gift to apply the sermons they heard, especially the one they listened to on the day of the interviews, to their lives. They do not convey these sermons to others frequently, but they would be able to edify and comfort others with it. The reason why they do not often do so was not established during these interviews. If they do talk to each other about the sermon of the day directly after the worship service (like with the interviews), this can enhance their confidence to convey the message to other people who do not partake in the worship services. It is important to continue research on the conveyance of preaching to develop a theory for this important aspect of homiletics.

\section{Acknowledgements Competing interests}

The author declares that he has no financial or personal relationship(s) that may have inappropriately influenced him in writing this article.

\section{References}

Atkinson, D., Akharwaray, N., Ingle, M. \& Van Schalkwyk, C., 2002, Linking IDPs to municipal budgets, local government support and learning networks (LOGOSUL), Department of Local Government and Housing, Northern Cape.

Atkinson, D., Pienaar, D., Van Schalkwyk, C., Du Plessis, R. \& Wellman, G., 2003, Life on the farm: Shifting social and moral foundations of the farming community, unpublished, Human Sciences Research Council, Bloemfontein.

Babbie, E., 2008, The basics for social research, Thomson Wadsworth, Belmond, CA.

Benatar, S.R., 2001, 'South Africa's transition in a Global World: HIV/AIDS as a window and a mirror', International Affairs 77(2), 347-375. http://dx.doi. org/10.1111/1468-2346.00196

Berkhof, H., 1979, Christian faith, Eerdmans, Grand Rapids.

Campbell, C., 2002, The word before the powers: An Ethic of Preaching, Westminister John Knox Press, Louisville.

De Klerk, B.J., De Wet, F.W. \& Letsosa, R.S., 2010, 'Exposure to vulnerability as a new opportunity in preaching the Gospel to vulnerable people', in M. Lindhardt \& H. Thomsen (eds.), Preaching: Does it make a difference?, pp. 105-108, Studia Homiletica 7, Aros Forlag, Frederiksberg.

De Klerk, B.J., 2013, 'Viva Vox Evangelii: The reforming of preaching: A Liturgical approach, in J. Hermelink \& A. Deeg (eds.), Viva Vox Evangelii - Reforming Preaching, pp. 280-294, Studia Homiletica 9, Evangelische Verlagsansta, Leipzig.

Denzin, N.K. \& Lincoln, Y.S., 2005, 'Introduction: The discipline and practice of qualitative research', in N.K. Denzin \& Y.S. Lincoln (eds.), The Sage handbook of qualitative research, pp. 1-32, SAGE, Thousand Oaks.

Desilva, D.A., 2000, Perseverance in gratitude: A socio-rhetorical commentary on the epistle 'to the Hebrews', Eerdmans, Grand Rapids, MI. 
Fretheim, T.E., 1984, The suffering of God: An Old Testament perspective, Fortress Press, Philadelphia.

Gibson, R.L. \& Reimold, W.U., 2008, Geology of the Vredefort impact structure: A guide to sites of interest, South African Council for Geoscience Memoir 97, Pretoria.

Green, G.L., 2002, The letters to the Corinthians, Apollos, Leicester.

Hall, D.R., 2003, The unity of the Corinthian correspondence, T\&T Clark International, London.

Hartwig, R. \& Marais, L., 2005, 'Farm-Worker Housing in South Africa: An Evaluation of an Off-Farm Housing Project', Housing Studies 20(6), 931-948. http://dx.doi. of an Off-Farm Housing Project',
org/10.1080/02673030500291165

Hermelink, J., 2007, 'The Theologica understanding of preaching hope in preaching as a language of hope', in C. Vos, L. Hogan, J. Cilliers (eds.), Preaching as a
language of hope, pp. 37-50, Studia Homiletica 6, Protea Book House, language
Pretoria.

Hinson-Hasty, E., 2002, 'Violence, vulnerability, and the suffering of God', Church \& Society January-February, 129-132.

Janse van Rensburg, J., 2007, 'Research methodology', unpublished presentation during a seminar on research methodology, 30-31 August 2007, Faculty of Theology, North-West University.

Jensen, D.H., 2005, Graced vulnerability: A Theology of Childwood, The Pligrim Press, Cleveland.

Jordaan, T., Puren, K. \& Roos, V., 2008, 'The meaning of place-making in planning: Historical overview and implications for urban and regional planning', Acto Structilia 15(1), 91-117.

Kim, C.H., 2006, 'Prophetic preaching as social preaching', Evangelical review of theology 30(2), 141-151.
London, L., 2003, 'Human Rights, Environmental Justice, and the Health of Farm Workers in South Africa', International Journal on occupational environmental health 9(1), 59-68. http://dx.doi.org/10.1179/oeh.2003.9.1.59

Long, T., 2001, Beyond worship wars: Building vital and faithful worship,The Alban Institute, Herndon VA.

Mathews, AP., 2003, Preaching that speaks to women, Baker Academic, Grand Rapids.

Orkin, M. \& Njobe, B., 2000, Employment trends in agriculture in South Africa, Statistics South Africa and National Department of Agriculture, Pretoria.

Ottoni-Wilhelm, D., 2014, Preaching vulnerability - Naming and neglegting reality: A Global perspective, unpublished, Societas Homiletica, viewed on n.d., from www.societas-homiletica.org

Pieterse, H.J.C., 2009, 'Prediking wat God ter sprake bring in die Suid-Afrikaanse konteks van regstellende aksie', in F.G. Immink \& C. Vos (reds.), God in 'n kantelende wêreld, bl. 250-273, Protea Boekhuis, Pretoria.

Pieterse, H.J.C., 2013, 'Prophetic preaching in the contemporary context of South Africa', In die Skriflig 47(1), 1-12.

Puren, K., Drewes, E. \& Roos, V., 2008, 'A Sense of place and spatial planning in the Vredefort Dome, South Africa', South African Geographical Journal 90(2), 134-146. http://dx.doi.org/10.1080/03736245.2008.9725320

Puren, K., Coetzee, H. \& Roos, V., 2011, A Hidden Dimension in Site Planning: Exploring Affective Experience as part of Sense of Place on the farm Kromdraai, Vredefort Dome World Heritage Site, South Africa, unpublished.

Statistics South Africa, 2004, Census 2001 data, Statistics South Africa, Pretoria.

Woolman, S. \& Bishop, M., 2007, 'Down on the farm and barefoot in the kitchen: Farm labour and domestic labour as forms of servitude', Development Southern Africa 24(4), 595-606. http://dx.doi.org/10.1080/03768350701577764 